\title{
Psychosocial aspects in the configuration of Social dynamics in native communities
}

\section{Aspectos psicosociales en la configuración de la dinámica Social en comunidades originarias}

BLAS-LAVARIEGA, Luz Maria $\uparrow$, CRUZ-CABRERA, Blasa Celerina and CASTILLO-LEAL, Maricela

\section{Instituto Tecnológico de Oaxaca / Tecnológico Nacional de México}

Universidad del Estado de Arizona, Estados Unidos de América.

ID $1^{\text {st }}$ Autor: Luz Maria, Blas-Lavariega / ORC ID: 0000-0002-7939-5513, CVU CONACYT ID: 479355

ID $1^{\text {st }}$ Coautor: Blasa Celerina, Cruz-Cabrera / ORC ID: 0000-0003-4694-4261, CVU CONACYT ID: 50347

ID $2^{\text {nd }}$ Coautor: Maricela, Castillo-Leal / ORC ID: 0000-0002-3281-4135, CVU CONACYT ID: 147104

DOI: $10.35429 /$ JUC.2019.8.5.6.15

Received April 08, 2019; Accepted May 30, 2019

\begin{abstract}
Faced with this global reality characterized by inequality and abuse, it was highly interesting to inquire about the situation of some indigenous communities and the way in which their structure is configured, as well as what the implemented conditions have allowed them to coexist before the multiple theoretical globalizing development proposals that seek to homogenize markets and culture. For this purpose, a qualitative quantitative mixed methodology was used, from a humanistic approach, which corroborated interesting results regarding the structure and functioning of the social dynamics of the community, allowing to evaluate and analyze the change and evolution of social organizations and institutions as well as of its interaction with the social reality, the modes of production, economic, cultural, political, ecological, etc., centered on the interaction of the individual with his environment, where all the possibilities of evolution or involution of the same are gestated, being It is possible to identify achievements and social possibilities for the improvement of community life as well as the generation of its history.
\end{abstract}

Social Dynamics, Psychosocial aspects, Original communities

\begin{abstract}
Resumen
Ante esta realidad mundial caracterizada por la desigualdad y el abuso, resultó altamente interesante indagar cual es la situación de algunas comunidades originarias y la manera en que está configurada su estructura, así como cuales han sido las condiciones implementadas que les ha permitido coexistir ante las múltiples propuestas teóricas globalizadoras de desarrollo que buscan homogeneizar los mercados y la cultura. Para tal efecto se utilizó una metodología mixta cualitativo cuantitativa, desde un enfoque humanista, la cual corroboró interesantes resultados respecto de la estructura y funcionamiento de la dinámica social de la comunidad, permitiendo evaluar y analizar el cambio y evolución de organizaciones e instituciones sociales así como de su interacción con la realidad social, los modos de producción, económica, cultural, política, ecológica, etc., centrados en la interacción del individuo con su entorno, en donde se gestan todas las posibilidades de evolución o involución de la misma, siendo posible identificar los logros y posibilidades sociales para el mejoramiento de la vida comunitaria así como la generación de su historia.
\end{abstract}

Dinámica Social, Aspectos Psicosociales, Comunidades originarias

Citation: BLAS-LAVARIEGA, Luz Maria, CRUZ-CABRERA, Blasa Celerina and CASTILLO-LEAL, Maricela. Psychosocial aspects in the configuration of Social dynamics in native communities. Journal-Republic of Colombia. 2019. 58: 6-15

\footnotetext{
* Correspondence to Author (email: zulmma@gmail.com)

$\dagger$ Researcher contributing as first author.
} 


\section{Justification}

The problem addressed in the present investigation has become an object of reflection on which the need arises to know the processes and actions that are being carried out by the communities object of analysis, which from the point of view of their Social Dynamics, have solved problems and faced difficult situations obtaining significant results, as they are, for the present study: Cuetzalan del Progreso in the Sierra Norte of the state of Puebla and Sta. Catarina Lachatao in the Sierra Norte of the state of Oaxaca.

These communities have similar characteristics observed in their social, economic, political and environmental configuration, which will allow them to understand their worldview as native communities immersed within the World order; and the way in which these communities have designed a social dynamic that has allowed them to preserve their identities, grow and maintain, over time despite globalizing proposals, a situation that was considered a preponderant reason for analysis.

\section{Problem Statement}

Given this global reality, it was interesting to know what the real situation of the aforementioned communities is regarding the Social Dynamics and what are the conditions that have been implemented to coexist with the global development proposals since they currently coexist in the territory national, 62 ethnic groups and approximately the same number of languages are spoken; in 2015 the total indigenous population in Mexico is $12,402.95$ and according to studies done by the National Commission for the Development of Indigenous Peoples (CDI) in conjunction with INEGI these are found in 64,172 locations encompassed in 494 municipalities, where only in Oaxaca there are 245 of it.

These groups are defined as communities that share ethnic identities, ways of life and speak an indigenous language, according to data from the National Institute of Statistics and Geography (INEGI). A large part of these villages have a structure that has allowed them to survive despite of the multiple development proposals including the globalization proposal, which seeks to homogenize markets and culture.
Taking into account the above, it was essential to know what communities have done in the construction of the internal processes of social dynamics that have allowed them to meet the needs and guide the events that have guided the actions to achieve a better quality of life for its inhabitants, promoting conscious, responsible and committed citizens, aware of their individual rights and public duties, capable of building collective interests, based on particular interests as well as the understanding of the world with the capacity to interpret, process, but in particular, build it responsibly and sustainably, favoring, human development through the design of strategies that have counteracted the risks that inherently entail belonging to a global community, as well as to the unpredictable nature.

\section{Methodology}

For the investigative development of the Social Dynamics (Guerrero 2001) of the communities under study, it was necessary, first, to make a theoretical journey that allowed us to understand, from a panoramic vision, their worldview and ideological position as original communities and determine how these communities have managed to preserve their identity, grow economically and sustain themselves, despite the modernization process.

For this, it was necessary to use a mixed qualitative-quantitative method, addressing the research from an ethnographic methodology in its first phase, using various techniques such as observational guides, active observation with immersion in the communities, binnacle, structured and unstructured interviews with staff of the community, video recordings and as well as the creation of a photographic archive resulting from all the previous activities; This stage was carried out under the methodological design of the Rincón ethnographic spiral.

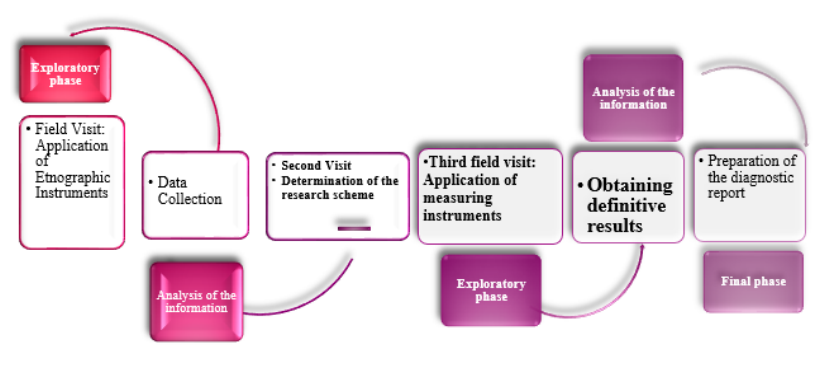

Figure 1 Rincon Ethnographic Spiral Source: Elaboración propia con base en datos del espiral etnográfica de Rincón feb 2018. 
a).- The exploratory and reflection phase: Initial phase, which defined the area of the problem and made the first contact with the objects of study, as well as the beginning of the review of the scientific literature to know what has been said to date regarding of the research topic.

b).- Planning phase: The resources and time available were defined and organized, at what time the communities would be contacted, when and how the information would be collected, how much time would be available in the data analysis.

c).- Stage of entry into the scenario: The sample was selected and the inclusion criterion was determined depended more on the quality of the information that is collected than on the quantity, this information together with the previous one allowed to elaborate the art study, the conceptualization and operationalization of the variables, as well as the elaboration of the theoretical and methodological scheme.

d).- Data collection and analysis phase: the various techniques were selected and the measurement instruments used were developed, the communities were visited for the application of the pilot and final questionnaire.

e).- Stage of withdrawal from the stage: This phase was characterized in that the data collection was completed, the data obtained from each of the techniques used were integrated and interpreted.

g).- Development phase of the research report: Communicate the results obtained, condensing the results of the techniques used in order to perform a process called triangulation of instruments in conjunction with the sociogram, cladogram as well as the comparative process in order to provide greater degree of reliability and validity.

Regarding the quantitative methodology, first, the processes of conceptualization and operationalization of social dynamics were carried out, the design of the measuring instrument, its application, data collection and processing. Taking into account the proposals of Jhon Twigg (2013), Munist and Santos (2012), as well as the proposal of Urie Bronfrenberner (2003), with ecological theory, 2 dimensions were defined that determined the Social Dynamics within the community.
They are the Sociological and Psychological breakdown in their respective dimensions, categories and indicators as can be seen in Figure 2: Model of social dynamics.

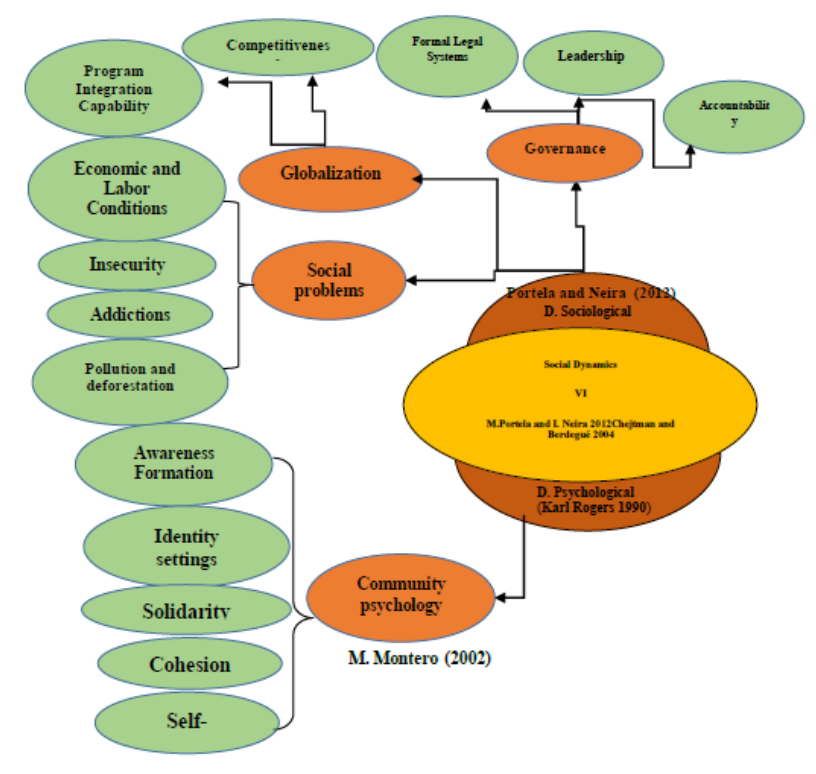

Figura 2 Modelo de Dinámica Social

Source: Elaboración Propia con base en diferentes autores Feb 2018

The Sociological Dimension It was defined as the set of social phenomena that occur in the interaction between institutions, organizations: social groups, family and situations, considering them within a social structure and historical moment, which determines the identity and social awareness of the inhabitants. Psychological dimension as the process resulting from the interaction of affective-cognitive and social areas that combine in all behavior of community members within the social group.

\section{Sociological Dimension: Categories and Indicators}

Social Problems: This category is defined as the condition that affects a whole community in a generalized way that makes everyday life difficult, being its indicators Economic and Labor Conditions, Insecurity, Addictions and Pollution and Deforestation.

Globalization: This Category is defined as the Integration of indigenous communities into the world market based on culture and identity to favor or promote their own economic and social development and their indicators are Competitive and Program Integration Capacity. 
Governance: Category that is defined as the technical and political capacity with which the authority has to exercise power and give solution to the demands of the community that favor economic and social development, being its indicators Formal Legal Systems, leadership, Surrender of Accounts.

Psychological Dimension: Category and indicators Regarding the Psychological dimension A category was identified, based on the theoretical proposal made by Montero (2002) considering

Community Psychology: Community Psychology It was conceptualized as the forms of behavior that allow community life, considering the affective and cognitive aspects, as a result of the interaction of organisms and institutions with the inhabitants, which shape their sense of belonging, identity and collective consciousness within a social context; Five indicators were identified: Awareness formation, Identity configuration, Solidarity, Cohesion and Self-management.

Subsequently, a questionnaire was designed on the Likert scale from 1 to 5 , where each indicator corresponded to 4 items, having a total of 56 questions, which allowed quantifying the data, once the information was obtained, it was statistically processed.

\section{Results}

The main objective of the first phase phase I, was the study of how the Social Dynamics is configured obtaining interesting results that allowed us to understand the internal processes of the communities subject to study and everything that constitutes them, as a result of the interactions of people with the rest of the society: culture, institutions, organizations and with the other members of its social field, determined by its history and subject to customs, beliefs, traditions, geographical situation and territory, marking a generalized behavior, which has shaped its identity, feeling of belonging and social awareness, characterized by the malleability that has allowed them to develop a whole resilient structure and achieve a better quality of life.
The graphs are shown below. resulting comparatives.

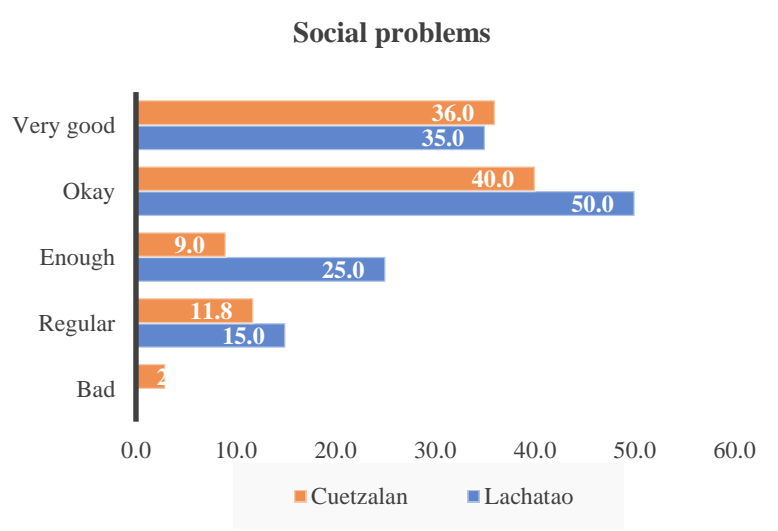

Graphic 1 category: Social problems

Source: Own elaboration based on research results May 2019

Social Problems is a category of the Sociological dimension and integrates the four indicators: Insecurity, addictions, Pollution and deforestation, working conditions it can be observed in general that in both communities there are conditions to counteract social problems with a small advantage for Sta.Catarina Lachatao since in relation to addictions, the community does not have canteens established by an assembly agreement, so the rates of alcoholism and drug addiction are nonexistent, which affects the conditions to counteract social problems, so there is no risk to break the stability of the community unlike Cuetzalan del Progreso.

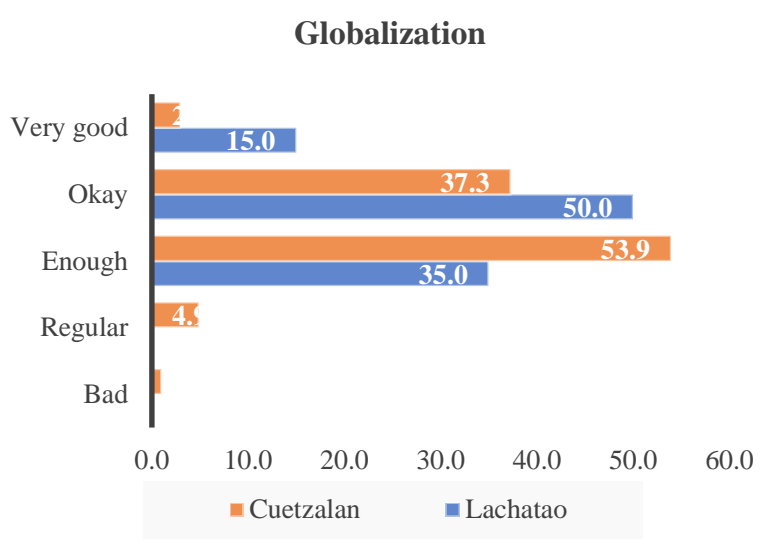

Graphic 2 Category: Globalization

Source: Own elaboration based on research results May 2019 
Regarding the importance of integrating, generating and participating in national programs for the communities, both communities consider it very important as seen in the graph and are working on the generation of various non-governmental organizations, cooperatives and associations that are promoting both economic as social development.

In this regard, Cuetzalan del Progreso has developed several programs with more consistency; both communities also consider that it is still necessary to develop more programs in order to grow the community without losing their identity, as can be seen in graph 2.

In relation to competitiveness, regarding the development of activities that rewards them to be attractive to tourism, as well as being able to compete with other communities in terms of products and services, although in the case of Sta.Catarina Lachatao does not develop handicraft products, they consider that there is a great tourist attraction with a new proposal called, community tourism (Palomino 2016) where visitors are offered experiences close to people and nature, in the same way that Cuetzalan del Progreso with the difference that this community produces various crafts and products; both communities are innovating in tourism programs and services.

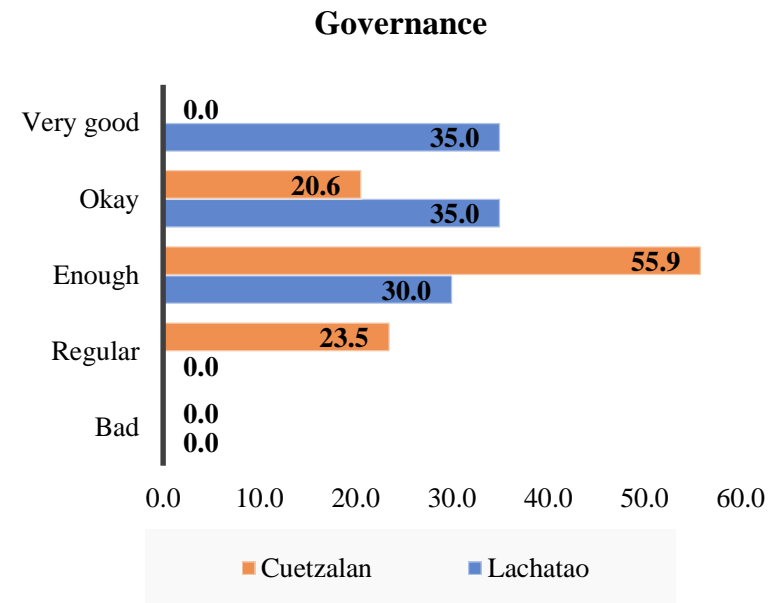

Graphic 3 Category: Governance

Source: Own elaboration based on research results May 2019
In relation to the category of governance with respect to the indicator: formal legal systems, as shown in graph 3 Sta. Catariana Lachatao considers that its structure is very solid, the council is recognized by the community, which is chosen by assembly, by customs and customs, accompanied by nongovernmental groups or committees to support the authority, formed by people from the community; In the case of Cuetzalan del Progreso, the representatives of the town councils are elected through political parties with a communal nuance of participation, where there are support groups for the authorities.

In relation to leadership where the authorities administer the assets and cooperations of the community, accountability is done through assemblies on the results of the actions; Lachatao believes that the authorities have the capacity to direct, work together with the support groups, listen to the proposals and propose new projects for the community, in relation to Cuetzalan del Progreso, consider that the authorities need to develop greater leadership and better relationship with the community organizations.

\section{Comparison of the Psychological Dimension}

Psychological Dimension

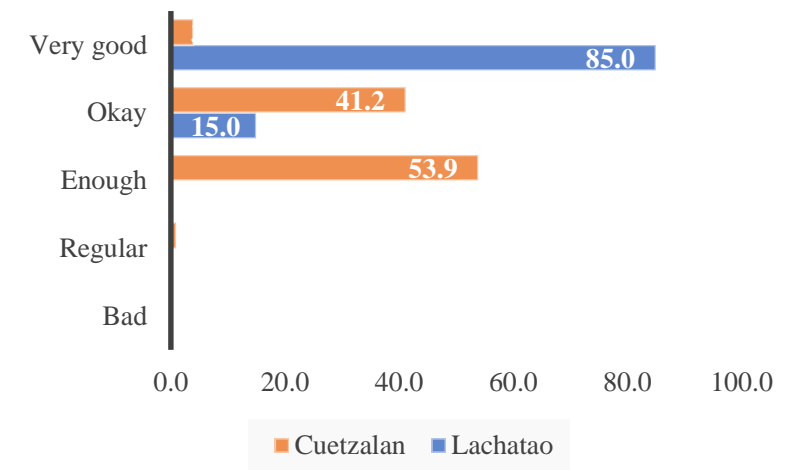

Graphic 4 Dimension: Psychological

Source: Own elaboration based on research results May 2019

Regarding the category Community psychology that includes as indicators the identity configuration, awareness formation, self-management, solidarity and cohesion; in the development of the investigation, as a result of the application of the instruments used, very important characteristics were identified in both communities, product of their worldview and of the self-concept that as original peoples they preserve very jealously.

BLAS-LAVARIEGA, Luz Maria, CRUZ-CABRERA, Blasa Celerina and CASTILLO-LEAL, Maricela. Psychosocial aspects in the configuration of Social dynamics in native communities. JournalRepublic of Colombia. 2019 
Among these are anthropologically inbred features (Vargas 2014), referring to the desire not to incorporate members outside the social group, jealous of the preservation of their identity, which triggers proposals and processes very characteristic of their ideology, proud of who were and remain.

This leads us directly to talk about the psychological dimension; how interesting it was to identify a close relationship between the sociological and the psychological, configuring the Social Dynamics, are the faces of the same coin, are so closely related, one leads to the other and she feeds back, and they could only be separated by issues study.

All this contributed to emphasize the psychological processes of the community, allowing to point out the observation in the mental health of the community in general (Sandoval 2004), since mental health is a primary concern today in all societies of the world, due to the increasing number of cases that are added year after year, and due to the high costs involved in being able to face what is already being considered as an urgent public health problem, from prevention, approach and rehabilitation of people with these types of conditions.

In this way it was important to consider it as an aspect worthy of being observed and identify its components such as: depression, anxiety that causes altered emotional states, anguish, neurosis, psychosis to schizophrenia, triggering various somatic diseases manifesting on a physical level, even antisocial behaviors such as frustration, violence and destitution and their adjuvant alcoholism, smoking and drug addiction.

For this, it was necessary to consider two aspects, first of all understand that it is mental health (Sandoval 2004) and define it as a state of well-being in which the individual is aware of their own abilities, being able to face the normal tensions of life, work in a productive and fruitful within a state of balance between his person and his socio-cultural environment that guarantees his labor, intellectual and relationship participation to achieve a well-being and quality of life being able to contribute and give back to his community.
And on the other hand to understand the health and emotional and mental well-being seen from their ethnic worldview, where everything in nature has a function to fulfill, not for itself but for others, to understand that the tree does not feed on its fruits if they are not for others, the flowers expand their aroma so that others can persist it, where everything in nature has a reason to exist, with greater reason the human being, nature's masterpiece.

The reason for existing on this plane is very important, and its existence has value depending on what you do for others which will nourish your soul giving meaning to your life. In such a way that identifying the worldview (Hinojosa and Ruiz 2015) allowed us to understand what are the reasons for the low incidence regarding emotional and behavioral problems as well as adjuvants such as alcoholism, smoking and drug addiction.

For example with respect to addictions, in Sta. Catarina Lachatao there is really no problem of addictions, they consider that the population size allows greater control; By arrangement of the assembly there are no established canteens, nor sales of any alcoholic beverage in grocery stores, that does not mean that they are not consumed, the drink that is taken is mezcal and is made in collective activities of the community or family.

Regarding the sacred silvers such as mariguna, poppy, foripondio, St. John's wort, tobacco, they are consumed only in ceremonies or as medicine for specific diseases by community healers and healers.

In Cuetzalan del Progreso there is a greater problem of addictions mainly alcoholism, it is interesting to emphasize that in the community there are five established canteens, and in the miscellaneous alcoholic beverages are mainly sold beer.

There is more indiscriminate sale and consumption of alcohol, in the same way, although it is not yet a daily practice in young people and adults, there is the consumption of sacred silver more frequently, without curative or ceremonial purpose. 
Alcohol consumption predisposes to a state of addiction and therefore to altered states of consciousness, violence and social problems, these behaviors if observed in Cuetzalan del Progreso, in an average percentage that does not have control if it could affect social dynamics, because there have been reports of violence and robberies, a situation that does not happen in Sta. Catarina Lachatao the reports of violence have not been carried out under this influence and robberies do not exist.

Regarding mental health problems, it was observed that depression and anxiety rates are minimal in both communities, comment that they have experienced them, but in situations of grief, family problems, or situations of some contingency in the community but that in none of the cases have been medicated, only in some occasions they are treated naturally.

So the way they solve and face emotional problems, whether personal or family, are in a socialized way, as a first alternative they turn to grandmothers and grandparents, godparents and godmothers who acquire very close commitments with the godson or goddaughter, which has a very important function within the community, occupy a relevant place after the parents and has the authority to draw attention, in the same way they turn to the village priest, the church or the cemetery to speak with their grandparents ; that feeling of accompaniment and belonging, strengthens their self-esteem and gives them support to solve the problems; problems everyone has at some point in life.

It is extremely interesting to identify that all aspects of life are socialized, in the most important events of a family such as births, baptisms, weddings and funerals the community is present with the help in species, economic and participation with accompaniment; in the same way when an accident or natural disaster occurs, in Sta. Catarian Lachatao and all the indigenous peoples of both the Sierra Norte de Oaxaca and central valleys it is called Guezaa, word from which the word Guelaguetza comes from, a tradition that is also found live in the community of Cuetzalan del Progreso.

It is surprising to recognize preventive processes as part of their own social structure, knowing what the development of a psychoaffective structure means.
This intensioned design is very interesting, since community accompaniment is extremely important in the development of cohesion, in the ability to manage from the individual to the collective, as well as in the formation of conscience, configuration of identity and in the elaboration of your own self concept. This whole process stimulates the development of high self-esteem for everything they know about themselves through history, fundamental characteristics that have allowed them to develop Community Resilience, in its four dimensions.

\section{Comparison of the Sociological Dimension}

What can be seen in figure 5 is that Cuetzalan del Progreso supports more its development in the social dimension, for its various cooperative organizations and existing groups, which has allowed them a higher level of economic development mainly generated by tourism since This is a magical town. Of course, Sta. Catarina Lachato is also working hard on this aspect, and there are various support groups, the social structure is communal, although they themselves recognize that it is necessary to further promote this aspect.

Sociological Dimension

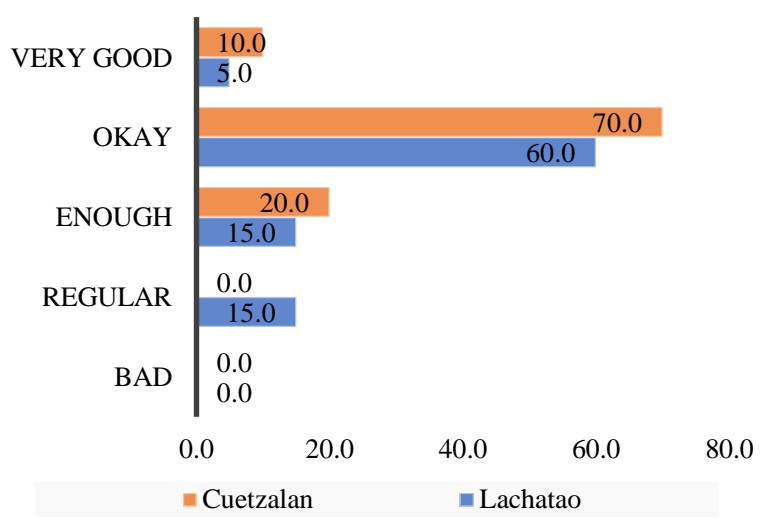

Graphic 5 Dimension: Sociological

Source: Own elaboration based on research results May 2019

In both communities, the sociological dimension is based on a strong social structure, millenary with minimal modifications until today, in the case of Sta. Catarina Lachatao that governance structure based on the system of charges consists in the execution of offices that are previously defined by a certain period, which are rotated among the members of the community. 
The offices are hierarchically arranged in three parts, those related to the political, social and religious and includes all members of the community, no payment is received during the period of service, on the contrary, it is more frequent that the position means a considerable cost in time of work invested and cash, but as compensation, the position gives the head a great prestige in the community and after having assumed the most important positions, it is considered as the main.

All these assignments are given within the assembly that is the highest authority, respecting this millenary structure that has remained until today, and that is the rector of all aspects of the social, economic, cultural, environmental and religious structure, characterized by being a community and called communality in the indigenous communities of the Sierra Norte de Oaxaca and Comunalismo in the Sierra Norte de Puebla. It is about the daily way of life in these communities, so it is not explicit, but it is always present and becomes evident at all times of life.

The community (Martinez 2015), is the ideology, thought and action that has allowed communities to face and solve challenges and problems that history has given them. Recognizing and recording this character has been an arduous work through which this community character and its manifestations have been shown in the different spheres of daily activity; The importance of understanding and preserving this way of life, focuses on the future of survival and transcendence of ancient peoples.

The communism (Korsbaek 2009) in the Sierra Norte of the State of Puebla, has survived over hundreds of years, in the municipalities and auxiliary boards of Cuetzalan del Progreso until today, there are small modifications such as the integration of the town hall by payroll, elected by the assembly and exercising its functions under the system of charges; unlike the head of the district that is Cuetzalan del Progreso, for several years now its system of election of the council is governed by political parties; Despite this, the basis of its social structure is communalism.
The participation of the community in the various social and cultural aspects is very active, which has allowed the essence of community life not to be lost, a very close contact, solidarity and relationship is observed and the soul of communalism lives on the day of Sunday morning square, listening to the majority of the inhabitants sing their mother tongue, the nahualt, when offering their products and in the daily talks.

\section{Acknowledgements}

I add to the National Technological Institute of Mexico, to the Postgraduate and Research Division of the Technological Institute of Oaxaca, to the Program for Professional Professional Development PRODEP, to Dr. Carlos Vélez Ibañez of the Arizona State University for his valuable support in the realization of the present investigation; and Ph.D. Blasa C, Cruz Cabrera and Maricela Castillo Leal, for the accompaniment in carrying out this research.

\section{Conclusions}

Following the results obtained, we can affirm the existence of a type of psychology, not in the way of feeling emotions or feelings, but in the way of persisting reality, the world and conceptualizing it with a very different vision, which transforms the meaning of life itself; It is interesting that there is an ethnic psychology with its own structure, which configures all the self-concept, identity and feeling of belonging and gives an emotional support that allows them to satisfactorily resolve emotional conflicts both at personal, family and community levels.

This structure based on communality and communalism is the opposite of individualism, the communal territory to private property; the compartment, to the competition; the exchange to the business; diversity to equality, tequio and slaughter of salary payment, being interdependent and non-dependent, where there are representatives not authorities.

The communality in the northern mountains of Oaxaca represented in Sta. Catarina Lachatao and its agencies and the Communalism in the Sierra Norte de Puebla represented in Cuetzalan del Progreso and agencies, is considered a way of naming and understanding the indigenous collectivism. 
It is more than a taste for the gregarious, it is actually a structural component of the indigenous peoples, without ever forgetting their centennial historical roots; a culture with a multiplicity of physical aspects, of knowledge and practices that differentiated them from other groups of communities; an own language and therefore an identity.

Certainly it is a practice based on their ancestral worldview, which has been strengthening over time as it has served the original peoples of the northern Sierra of Oaxaca and mainly Sta. Catarina Lachatao and Cuetzalan del Progreso where yes communality and communalism were only one characteristic, there would be no way to propose them as the axis of community life, the reality is that it is something omnipresent, respected, considered as their own and therefore transterritorial in force, that is, even outside the community, to adapt communal life within the globalized world.

So that understanding this logic allowed us to understand how the social structure works and the way in which everyday life is defined and articulated that permeates everything and everyone, in all areas of life, in their feelings, in their thinking, in their perception of the world, in the configuration of their self-concept, giving them a feeling of security, of accompaniment at all stages of life and that has allowed them to organize in such a way that they have successfully cohabited in a globalizing world, without losing their identity.

\section{References}

Abreu, J. (2012). Constructos, Variables, Dimensiones, Indicadores y Congruencia. International Journal of Good Conscience.

Anandya, S. (1997). Concepts of human development and poverty: a multi-dimensional perspective, Nueva York: Human Development Papers.

Cazau, P. (2006). Introducción a la Investigación en Ciencias Sociales. Módulo 404, Buenos Aires: Tercera Edición Red de Psicología.

Diosey R.. y Lugo M. (2010). La etnocompetitividad Elemento de las estrategias de reproducción de los grupos sociales. Toluca, México: El Colegio Mexiquense, A.C.
Gibbs, M.S. et al. (1980). Comunity psychology. . Nueva York, U.S.A.Gardner.

Guerrero, L. (2001). Dinámica Social y Contenido Fenomenológico de la Expresión y Significación. Chile. Universidad de Chile.

Griffin, k. (1989). Alternative Strategies for Economic Development, Londres:MacMillan.

Hinojosa Rodríguez, A. y Ruíz Ledesma, J. (2015). Sustentabilidad y cosmovisión del pueblo Nahua de Cuetzalan del Progreso Puebla, México. Revista Mexicana de Ciencias Agrícolas, vol. 1, 2015. México. Instituto Nacional de Investigaciones Forestales, Agrícolas y Pecuarias Estado de México.

Merton r.k., \& Nisbet r. (1976). Contemporary social problems. New York U.S.A. Harcourt Brace Jovanovich.

González Montaño, M. (2016). Guía de práctica comunitaria. México. Escuela Nacional de Trabajo Social, UNAM.

Korsbaek, L. (2009). "El comunalismo: cambio de paradigma en la antropología mexicana a raíz de la globalización" Dossier: Pueblos originarios. México: cultura y poder Argumentos vol.22 no.59.

Martínez Luna, J. (2015). Conocimiento y comunalidad. Bajo el Volcán, vol. 15, núm. 23, septiembre-febrero, 2015. México. Benemérita Universidad Autónoma de Puebla Puebla.

Merleau-ponty, M. (1994). Fenomenología de la Percepción. España. Editorial Planeta- Agostini. Montero, M. (2003). La psicologia comunitaria: orígenes, principios y fundamentos teóricos Revista Latinoamericana de Psicología, vol. 16, núm. 3, 1984. Colombia..Fundación Universitaria Konrad Lorenz Bogotá.

Palomino Villavicencio, B. (2016). El turismo comunitario en la Sierra Norte de Oaxaca: perspectiva desde las instituciones y la gobernanza en territorios indígenas. México. Publicación Semestral Número: 30 Enero / Junio, Universidad Autónoma del Estado de México.

Sabino C. (1986). El proceso de investigación. Caracas, Venezuela..Editorial Panapo. 
Schejtman, A. y Berdegué, J.A. (2004). Desarrollo territorial rural. Documento. Chile: FIDA-BID.

Sandoval Juan M. (2004). Salud Mental en México. México. Investigador Parlamentario en Política Social. Cámara de Diputados.

Saraceno E. (2003). Enfoque Territorial del Desarrollo Rural, San José, Costa Rica: Agris.

Vargas Cetina G. (2014) Antropología Rural. Yucatan Mex. Facultad de Ciencias Antropológicas Universidad Autónoma de Yucatán.

Velez Ibañez, C. y Heyman J. (2017). México Transvorder Región, by Arizona board of Regents. E.U. Universidad del Estado de Arizona.

Villasante, T. (2003). Métodos Cualitativos. España: El viejo Topo. 